\title{
SOME NOTES ON A CONTEMPORARY REVIEW OF EARLY FRENCH HAEMATOLOGY*
}

\author{
by \\ M. L. VERSO
}

IN the early nineteenth century, a period when French medicine was at its zenith, one of the fields in which French investigators were particularly active was the study of the blood and its disorders. For this reason, an authoritative contemporary survey of the state of haematology in France at that time might be expected to have considerable significance for the haematologist, the clinician, the pathologist and the student of medical history. When it also describes some of the important general pathological concepts of the period, discusses many aspects of the earlier history of haematology, and supplies a selected list of references to earlier works on blood, its value is increased manifold. Such a review can be found in the article on blood in the Dictionnaire de Médecine et de Chirurgie Pratique of 1835 , an authoritative publication whose editorial panel included such outstanding figures in French medicine as Andral, Cruveilhier, Dupuytren and Magendie, as well as others less well known. The article on blood in particular represented the most expert opinion then available; the joint authors were Andral of Paris and Forget of Strasbourg. Although Forget was a relatively minor figure, the senior author, Gabriel Andral, Professor of General Pathology at the Paris Medical School, Member of the Royal Academy of Medicine and member of the staff of the Charité Hospital, was an outstanding pioneer of haematology. Dreyfuss (1957) has bestowed on him the title of 'Grandfather of Haematology', the title of 'Father' being reserved for another Frenchman, Georges Hayem.

A few years after the appearance of the review under discussion Andral published, in 1843, a full-sized book on haematology, Essais d'Hematologie Pathologique, which was a landmark in the scientific study of the subject. However, he did not confine his interests within a narrow speciality but was a versatile physician and pathologist who wrote prolifically on many subjects. Two of his outstanding works were Clinique Médicale which was published in 1824 and Anatomie Pathologique which was published in 1829 .

Relation of Blood to Other Tissues: Solids and Liquids

Andral and Forget commenced their discussion of blood by pointing out that its constituents were derived from the digestive and respiratory tracts, and that it was, in its turn, the source of the materials from which all the other

* Read at a meeting of the Section of Medical History in the British Medical Association (Victorian Branch) on Monday, 7 December 1959. 


\section{L. Verso}

tissues of the body were built up. They pointed out that from the earliest times the importance of the blood in the bodily economy had been recognized, and in the Old Testament the soul was said to lie in the blood. The actual words they used were 'l'ame de la chair est dans le sang' (the soul of the flesh is in the blood). This may be compared with the Authorized Version of the Bible which says 'the life of the flesh is in the blood' (Leviticus xvii. 2). The word 'soul' as used here meant the force that distinguishes living from dead matter, the Lebensgeist the life-force, or, in the original Hebrew, the 'nefesh'. It did not mean the spiritual soul.

They said that in ancient times, under the influence of humoral theories of disease, many false interpretations of natural phenomena had been made and many unfortunate therapeutic practices had grown up. Therefore it had not been surprising that with the advent of 'solid' pathology, that is, the systematic study of morbid anatomy and the structural changes in tissues and organs in disease, a reaction had occurred against anything savouring of 'humorism'. They believed however that this reaction had gone too far with the result that the legimitate study of the body fluids or 'humours' had been neglected. For their part, they believed that to gain a true understanding of physiology and pathology it was not sufficient to study structural changes but one also needed to study the body fluids. They agreed with Bichât that all theories based exclusively on either 'solidism' or 'humorism' gave an inadequate concept of physiology and pathology. There was no sharp distinction between the chemical composition of solid tissues and that of body fluids, and one could not be modified without modifying the other. Therefore in discussing one of the body fluids, the blood, they took the opportunity to put forward a plea for the revival of modified humoral concepts based on scientific studies.

\section{Studies of Normal Blood}

Andral and Forget believed that the weak point in earlier humoral theories had been that they were based on speculation and their originators had lacked the essential chemical data necessary to put them on a scientific basis. It was not until the seventeenth century that attempts at chemical analysis of the blood had been made and those early attempts had been of historical value only. Up to the middle of the eighteenth century real knowledge of the blood had been limited to the microscopic studies of Leeuwenhoek and those who had followed him, and the knowledge that iron and salts were present in it, but from that time on many chemists had become interested in the analysis of blood. Andral and Forget were well aware that analyses of blood made by various workers differed both as to the nature of the constituents and their concentrations. Such discrepancies were due to the inadequate analytical methods of the day. However, there was general agreement that certain substances were present in the blood including water, albumen, fibrin, 'colouring matter', fatty crystallizable matter, oily substances, extractive substances soluble in water and alcohol, iron salts, the chlorides of sodium and potassium and the carbonates of calcium and magnesium. 


\section{Some Notes on a Contemporary Review of Early French Haematology}

Some of these substances warrant further comment. Fibrin was thought to be merely insoluble albumen bourd to certain salts, while the colouring matter, which had been called 'haematosine' by Berzelius and 'cruorine' by Denis, was regarded as a combination of albumen with a substance containing a high proportion of iron to which M. Le Canu had given the name of 'globulin'.

It was recognized that substances derived from other secretions were sometimes present in blood. M. Orfila and his co-workers had reported the presence of the 'yellow matter of the bile' in the blood of icteric patients and Prevost and Dumas had detected urea in the blood of dogs whose kidneys had been extirpated. However, M. Raspail had criticized this experiment and suggested that the urea could have been produced by the extraction procedure. M. Le Canu believed that since bile sometimes occurred in blood it was reasonable to infer that the constituents of other tissues and secretions might also be present even though they could not be detected by the chemical procedures available. It was also realized that a substance might be present in sufficient quantity to cause physiological effects without being detectable by chemical means. Oxalic acid was given as an example of such a substance.

\section{Blood Coagulation}

A number of theories had been put forward to explain the phenomenon of blood coagulation and the subsequent clot retraction. Denis and others thought that coagulation was due to the 'death' of the blood and the loss, after shedding, of a vital principle that normally maintained it in the liquid state in the circulation. John Hunter had regarded clot retraction as a vital process, a true contraction, of the same nature as muscle contraction. Others had suggested that the retraction was due to galvanism.

As opposed to these vitalistic theories, M. Raspail thought that the albumen in the blood was kept in solution by an alkali and that after shedding, the carbonic acid of the atmosphere, along with that released from the blood itself, neutralized the alkali and released the albumen from solution to form fibrin which was the basis of the clot. The precipitation of the albumen was thought to be aided by the evaporation of a certain amount of water and ammonia from the shed blood. Andral and Forget agreed with the view that coagulation could be explained by simple chemical and physical laws and that there was no need to invoke vitalistic explanations of the process.

\section{Modification of Blood under Physiological Conditions}

A number of studies had been made of the variations in blood under physiological conditions. The proportion of serum to clot was said to be higher in females than in males and to be higher in lymphatic than in sanguine individuals. Contrary to the generally accepted idea that the constitutions of adolescents were more humid than those of the elderly, no relationship had been observed between the age of the individual and the ratio of serum to clot. The difference between the two age groups, Andral and Forget said, lay not in the proportion of serum to clot but in the greater rigidity of the tissues in the aged. 


\section{L. Verso}

The ratio of globules to serum in the blood was thought to be a measure of vital energy. Thus, it was greater in birds and carnivores than in herbivores and in robust and plethoric individuals than in the weakly. However, the differences between the two sexes was not thought to be due to differences in vital energy but to the fact that females had to cope with the regular drain of the menstrual cycle. Seasonal variations, individual idiosyncrasy, and above all the state of nutrition could influence the concentration of the globules. The factors that caused variation in the red cells caused similar variations in the 'nutritive substances' such as albumen, fibrin and 'colouring matter'.

Since blood was formed from substances derived from the digestive and respiratory tracts, it was thought that variations in the state of these absorptive passages could alter the state of the blood. The state of the innervation could also affect the blood and, at the same time, the state of the blood could affect the nervous system. Thus coagulation in the pulmonary vessels had been produced by ligature of the vagi. Again, Lobstein regarded erection as the result of 'expansion' of the blood under nervous influence. Excessive innervation, that is, excessive nervous influence, was thought to be one of the features of inflammatory disorders. Blushing under 'moral', that is, mental or emotional stimuli was regarded as evidence of the action of the nervous system on the blood. Modification of the consistency of blood was said to occur in convulsions, while diminution of nervous action was said to be associated with profound alterations in the blood in cholera.

\section{Variations in the Blood in Disease}

In discussing the alterations that took place in the blood in disease pride of place was given to the consideration of the variations that might take place in the total quantity of the blood. When the quantity of blood was excessive hyperaemia was said to be present. Hyperaemia could be local or general, sthenic or asthenic. Local hyperaemia was not necessarily associated with general hyperaemia.

Andral and Forget's description of general sthenic hyperaemia could well be applied to polycythaemia vera. However, although among their hyperaemic patients there were no doubt a number of patients suffering from polycythaemia vera, probably the majority were not and it is quite likely that a plethoric appearance would have sufficed for physicians in those days to have put a person into this category. This type of hyperaemia was said to give rise to a number of secondary effects including fever, phlegmasias, haemorrhages and hydropsies. These effects were thought to be due to the transudation of blood or one of its elements into the tissues as a result of either overfilling of the circulation or an excessive impulse from the heart.

Asthenic hyperaemias were said to be caused by a super-abundance of blood which had been deprived of its stimulating properties or was stagnant in the circulation. General asthenic hyperaemia was said to occur in diseases of diverse nature and, although a general condition, it could give rise to local symptoms. The local asthenic hyperaemias included such conditions as passive 
congestions, chronic inflammations, gangrene, haemorrhagic states, hydropsies and fluxes.

Another form of hyperaemia was the mechanical type which was said to arise from obstruction to the circulation. Although it was the result of a localized lesion, it could give rise to such general clinical effects as cyanosis, haemorrhages and hydropsies. Gadaveric hyperaemia was a type whose features should be known, they thought, so that it could be recognized in the cadaver.

Diminution in the quantity of blood in the body was said to constitute anaemia. It could be associated with most chronic maladies or could arise from food deficiency or loss of blood. It was the predominant feature of chlorosis. Elderly people were often thought to be anaemic when they were not so, for their features were often pale due to the obliteration of the superficial vessels even though the actual quantity of blood in the body was normal. Old people were said to stand venesection well.

The next series of changes studied were the alterations in the physical properties of the blood. The first of such properties discussed was consistency. Increased consistency was often associated with plethora, and in fact Andral and Forget distinguished between two types of plethora, one in quantity, that is, hyperaemia, and the other in quality, where there was a relative predominance of the solid elements without an increase in the total volume of blood. They said that thickening of the blood could be recognized in two ways, firstly by the slowness with which the blood flowed from the vein, and secondly by the relative increase in the volume of the clot. Thickening of the blood was thought to arise either from an excessive haemopoietic activity or from the abstraction of the liquid portion. This might occur from such conditions as cholera, fluxes and certain hydropsies. In other words, it could occur as the result of dehydration. In these cases the blood had a syrupy consistency. It was thought that the slowing of the circulation that could be observed microscopically in inflammation might be due to a local thickening of the blood.

It was thought also that if the blood became too thick and it slowed down too much, intravascular clotting could occur. The fact that blood would clot if the circulation was slowed down sufficiently was the basis of the treatment of aneurysm by ligature, and it was suggested that the injection of substances known to cause coagulation might also be used to treat this condition.

Decreased consistency or excessive fluidity of the blood was said to coincide as a rule with anaemia. Usually this type of anaemia arose from faulty nutrition as in scurvy but it could also arise from certain fevers and cachexias, scrofula and chlorosis.

The treatment of changes in the total quantity of blood in the body and of changes in consistency were the same. If the patient was plethoric, whether from excessive blood or from thickened blood, venesection was the treatment. If the patient was anaemic, improvement of nutrition was the treatment. They thought that in these disorders the appropriate medical treatment was more successful than in any other branch of medicine and they were the only condition where the effectiveness of medical measures approached that of operative 


\section{L. Verso}

procedures in surgical conditions. However, they realized that if anaemia arose from certain fevers and cachexias, treatment was of little avail.

The next physical property dealt with was colour. It had been shown experimentally that colour changes could be produced by treating blood with certain gases. Thus, blood turned bright red after exposure to oxygen or ammonia, brown with hydrochloric acid gas and brownish black passing to white with chlorine. Under various physiological and pathological conditions analogous changes could occur in the circulating blood. In delicate people, in 'lymphatic' types, in anaemia and after haemorrhages the blood was said to be pale and serous. In melancholics, hypochrondriacs, in heart disease, scurvy, epidemic cholera and certain fevers the blood was said to be black due to the abstraction of the 'saline principles'. Venous blood was said to be clear and vermilion when the circulation was rapid as in inflammatory fevers. Sometimes the blood was found to have a milky appearance thought to be due to the presence of fatty material. Besides the colour changes in whole blood, a number of alterations in the colour of the serum were recognized. Serum was said to take on the colour of soluble substances mixed with it. Thus, it was yellow in icterus and after the ingestion of rhubarb. Other colour changes recognized in serum were a lemonyellow colour in inflammatory maladies and a whitish colour in peritonitis and in parturient females.

Variations in the taste of the blood had been little studied. However, in two female syphilitics it had been found to have a saltier taste than normal, in rickets the blood was said to have an acid taste, and in icterus it was known to have a bitter taste. No comment was made on the taste of the blood in diabetics.

A number of observations had been made on the odour of blood in various conditions. Thus, blood was said to have a nauseous odour in scurvy, confluent smallpox and in malignant and putrid fevers. However, Haller had pointed out many years before that the odour attributed to the blood in smallpox might, in actual fact, arise from the pustule itself. Blood treated with sulphuric acid was said to have an odour characteristic of the animal from which it had been obtained. They thought that this fact might prove to be of practical value not only from the medico-legal, but also from the clinical point of view. If blood, known to have come from a human source, was treated with sulphuric acid and failed to emit a human odour it could be concluded that it had undergone some alterations.

Variations in the heat of the blood in different maladies had received a certain amount of attention by a number of workers and the amount of heat lost when blood was allowed to stand had been compared in different diseases. The value of these figures was vitiated however by the fact that the time interval over which these changes took place was not stated.

Allied to the study of the temperature variations of the blood was the investigation of its electrical properties. In fact, these two properties of matter were often studied together as thermo-electricity. Andral and Forget were only a generation or so removed from Volta, while the pioneering work of Galvani, Ampère, 


\section{Some Notes on a Contemporary Review of Early French Haematology}

Oersted and Ohm had been carried out a few years before their review was published. They were contemporaries of Michael Faraday. In other words, they lived in a period when many of the basic facts about electricity were discovered and when it was a very live subject attracting considerable interest in scientific and medical circles. With the crude measuring instruments then available only gross measurements could be made, but experimentalists, ignorant of the limitations of their methods, enthusiastically embarked on the study of the electrical properties of blood in such conditions as rheumatism, gout, 'peripneumonie', hydrothorax, phthisis and syphilis. These experiments seemed to show that the electrical state of blood differed in these conditions from its electrical state in health and that in health it contained more electricity than in inflammatory states. It was suggested that in these conditions the blood gave up its electricity to the tissues. It was also said that serum separated from its clot had no action on the electrometer. Opinions differed as to whether the application of electricity to the blood resulted in a gain or a loss of heat: Different workers had obtained contradictory results on this point which could probably be attributed to the crudity of their apparatus.

On sounder lines were the attempts to use electricity therapeutically, for apparatus had been invented to attempt to soothe painful parts by the application to, or as they said, the 'extraction' of electricity from, the affected area.

Another change that could sometimes be observed in the blood in disease was the presence of gas. Hippocrates had been aware of the existence of such a condition as 'gaseous apoplexy' and in more recent times many observations had been made on this condition. However, disagreement existed as to how gas got into the circulation. Some thought that it might arise from alterations in the blood itself while others believed that it was introduced through the respiratory passages. Andral and Forget were among those who believed that it developed as a result of alterations in the blood itself, for it was well known that gas could sometimes appear after the introduction of septic material. Many experimenters had studied the problem of gas in the circulation after the injection of air into the blood vessels. Magendie in 1821 had observed air embolism in a patient operated on for a tumour of the shoulder. Since then this accident had been observed on a number of occasions and it was regarded as one of the chief hazards of operations in the neighbourhood of the great venous trunks.

One of the most important changes that was studied in the blood in those days was the formation of a 'buffy coat' in certain conditions. Andral and Forget regarded this 'buffy coat' as the result of a loss of 'colouring matter' by the superficial part of the clot. They said that the buffy coat was a layer of variable thickness which could be modified by a number of extraneous circumstances apart from any condition from which the patient might be suffering. Thus, the size of the incision into the vein, the manner in which the blood flowed and the temperature of the collecting vessel might all affect the nature of the 'buffy coat'. Nevertheless, other things being equal, this layer was known to be more 
prominent in certain conditions such as plethora, pregnancy, intermittent fever, yellow fever, haemorrhagic states, active hydropsies and inflammations of the parenchymas of organs, serous membranes and joints. After repeated bloodletting the 'buffy coat' usually ceased to form and this was regarded as a good index of the effectiveness of the treatment.

It had been noted that a 'buffy' coagulum could form in the supernatant serum above the clot and it was concluded that the 'buffy coat' was composed of albumen. It was known also that in conditions associated with 'false membranes' the more 'buffy' the blood, the greater the amount of 'false membrane'. It was suggested that serous exudates became more acid in inflammation and that this acidity was the cause of the coagulation of 'albumen' on inflamed serous surfaces. It was also suggested that it would be interesting to find out whether blood with a marked 'buffy coat' was more acid than normal and whether it would have any effect on the buffy coat if blood was treated by the same methods that were employed to prevent the formation of false membranes in, for example, croup. Presumably the authors meant some form of alkalinization.

The next group of changes which they said might occur in blood were those due to the entry of various substances of a disease-producing nature into it. They thought that such substances could arise from within the blood stream itself, could come from other tissues and organs, or could be introduced into the circulation through the absorptive passages or by injection. In practice, they said, it was difficult to determine in any individual case how they had gained entry into the circulation. They recognized the fact that chemical methods were often unsuccessful in detecting these substances which in many cases could only be detected by their physical or physiological effects.

Various investigators had shown that a number of substances could pass through the digestive organs into the circulation. Examples mentioned included indigo, cochineal, gum ghatti, rhubarb, camphor, musk, alcohol, turpentine, asafoetida, certain potassium salts and certain iron salts. Since these substances could enter the circulation after absorption from the digestive tract they thought it was logical to believe that the poisons producing disease could also get into the blood in the same way. The rather unsuitable example given was the 'poison' causing 'scorbutic cachexia'.

The respiratory tract was regarded as potentially an even more important portal of entry for morbid material, for respiration is a process that is going on continuously and, what is more, the most minute morbid elements could, it was thought, be taken up by this route, including those causing various kinds of asphyxia as well as various effluvia and miasmata.

The doctrine of 'organ sensibility', whose chief advocates had been Haller and Bichât, was one of the main obstacles to the general acceptance of these views on how morbid material entered the circulation. This doctrine implied that organs and tissues were endowed with a special sensibility which enabled them to take up only those substances appropriate to the animal's economy while rejecting harmful substances. Although Andral and Forget believed that there 246 


\section{Some Notes on a Contemporary Review of Early French Haematology}

was some truth in this view, they pointed out that this 'eclectic sensibility' of organs and tissues was often at fault. Thus, the lining membranes of arteries, veins, intestines and bladder had been shown to be permeable to such poisonous substances as nux vomica or tobacco. Absorption could be altered under certain conditions but it was often obligatory.

Andral and Forget believed that certain features in the symptomatology of a number of complaints were the outward manifestations of changes occurring within the body. Thus, malaise and chills were thought to indicate the invasive stage of a fever when morbid material was being introduced into the body, while a crisis characterized by sweating, urination, diarrhoea, petechiae, buboes and gangrene was thought to indicate the attempts of the body to get rid of toxic material. These views supplied the rationale for the methods of treatment to be used, for such methods as venesection, purgation and diaphoresis were attempts to aid the patient to eliminate the morbid agent.

\section{Experimental Transmission of Disease}

The view that many diseases were caused by the introduction of morbid material into the circulation had led a number of investigators to undertake experiments on the transmission of infective conditions. Andral and Forget mentioned several of them. In 1822 M. Gaspard had published experiments demonstrating that putrid matter injected into the veins of an animal would give rise to a number of symptoms and lesions analogous to those observed in certain spontaneous diseases. In 1826 Mm. Leuret and Dupuy had injected blood from a horse affected with anthrax into a healthy horse. The disease had developed in the second animal. M. Gendrin had also reported the case of a patient suffering from a putrid fever, presumably a septicaemia. One ounce of blood from this patient when injected into a cat had produced an acute febrile illness fatal in a few hours. At autopsy haemorrhages into various tissues and organs had been found. Blood from an epistaxis in the same patient, when injected into a dog, had produced the same chain of symptoms and the animal had suffered the same fate as the cat. M. Gendrin had also performed several experiments in which he had injected into animals blood from patients with confluent smallpox. Very severe and rapidly fatal symptoms had developed, and on opening the bodies of the animals several organs had been found to be inflamed.

Another worker, Duhamel, had reported an incident where several people had accidentally come into contact with blood from a bull suffering from anthrax and had developed the disease. Two of these people had died.

One interesting question discussed by Andral and Forget was whether viruses existed. By 'viruses' they did not mean what we do today. The word was used in a more general sense and simply meant a morbid poison, particularly one that entered the body by penetrating the skin. The evidence for the existence of viruses was not regarded as being as definite as that for the existence of miasmata. However, the fact that simple contact with infected blood could give rise to disease was regarded as strong evidence that these agents actually existed 


\section{L. Verso}

and on such premises the existence of viruses in variola, hydrophobia and syphilis, as well as in anthrax, was also suspected. Moreover, as many substances were known to be capable of penetrating the skin, it was thought logical that morbid agents might exist that could also do so. The belief that medicinal agents could pass through the skin was the basis of 'endermic medication', such as the use of mercurial inunctions, which had a vogue at that time.

On the basis of these clinical and experimental facts, Andral and Forget formed the general conclusion that substances could enter the body by alimentary, respiratory or cutaneous absorption to give rise to alterations in the blood and produce certain diseases. Among the conditions they believed arose in this manner were intermittent fevers, typhus, yellow fever, plague and eruptive maladies.

\section{Effect of Blood on the Bodily Economy}

The next topic discussed was the effect of alterations in the blood on the other tissues and organs of the body. This subject was regarded as important because of its possible bearing on treatment. To illustrate how changes in the blood could affect other tissues Andral and Forget mentioned, without detailing, some experiments on gravel made by Magendie. Another illustration was the raised level of the uric acid in the blood in gout. These findings, they suggested, raised the possibility that up to a point, one might be able to prevent and sometimes cure these complaints by restricting the intake of nitrogenous foods, which, they said, favoured the formation of urea which was the basis of urinary and arthritic concretions. The confusion between uric acid and urea here is obvious. They also thought that retention of the constituents of urine in the blood might be the cause of 'urinary fever' and that the excess of bile found in the blood in icterus might be the cause of 'bilious fever'. Here we have examples of how cause can be confused with effect.

One of the points about which physiologists were in doubt at that time was whether a substance found in the blood in excessive quantity arose from the resorption of secretions from other parts into the blood or whether it was the result of an accumulation of a substance already existing in the circulation. Speculation on this subject gave rise to some interesting remarks on pus formation which illustrate some of the general pathological concepts current at that time. One of the main points at issue was whether pus formed locally in the tissues by irritation, or whether it was absorbed from the blood and deposited at the affected site. Morgagni had been one of the foremost proponents of the former view while the latter concept was that held by the ancient writers. Andral and Forget were not prepared to come down firmly in favour of either side but said that the two views were not mutually exclusive.

Concerning suppuration in clots, Cruveilhier had suggested that pus was secreted in the vessel wall and from there infiltrated into the centre of the clot. However, Andral and Forget pointed out that the walls of a vessel containing a suppurating clot were not always inflamed and, furthermore, it was difficult 


\section{Some Notes on a Contemporary Review of Early French Haematology}

to see how pus could pass into the centre of a clot as suggested. Therefore they did not agree with Cruveilhier's ideas but thought that pus developed in the clot itself, claiming that recent microscopic observations supported this view.

Another pathological process, where considerations similar to those operating in pus formation were to be taken into account, was the formation of atheromatous plaques, or 'calculous concretions', as they called them, in blood vessels. They were generally thought to form in the thickness of a vessel wall, but an alternative theory was suggested, namely, that they arose in small blood clots adherent to the vessel walls. The fact that this theory was put forward at that time is of interest today because of its revival in recent years by Duguid (1946), who, in discussing the role of adherent clots in producing atherosclerosis, stated that the same theory had been held by Rokitansky (1852). However, from what has been said above, it appears that the theory had been put forward several years before Rokitansky's book had appeared.

The presence of living organisms in the blood had been observed from time to time and they were thought to arise from the vessels as a result of 'the organizing powers of blood'. Andral and others had found hydatids in pulmonary veins and other species of entozoa had been found in animals.

A number of cases were known of tumour tissue being found in the blood. For example, Andral himself had performed an autopsy on a woman who had had massive infiltration of her abdominal lymph nodes with tumour tissue, similar tissue in the liver, spleen and lung, and an infiltration of several branches of the pulmonary artery with the same tissue.

Andral and Forget concluded their review by repeating their plea for the revival of a modified form of humorism for they thought that many general phenomena could best be explained by studying variations in the body fluids. They thought that many ideas had been rejected on paltry grounds. Since all theory is reflected in practice they felt that a regenerated humorism would produce a number of reforms in the treatment of disease. However, the major methods of treatment would not be affected to any extent for, they said, it is not hypotheses that cure but remedies whose efficacy has been demonstrated in practice. Medical practice must continue to be based on practical experience. Thus, it was known from experience that one should bleed to evacuate vicious principles from the blood and purge to evacuate noxious matter from the bowels. The great therapeutic methods would remain regardless of the rise and fall of various systems and theories.

\section{Conclusion}

Obviously many of the views put forward by Andral and Forget and their contemporaries are quite unacceptable in the light of present day knowledge and many of their observations were faulty. This was due, in large measure, to the inadequate methods they had at their disposal and to their failure to realize the limitations of their techniques. Nevertheless, many of their views were sound and many of their observations were correct. The outstanding thing about these 


\section{L. Verso}

men was that they had a modern approach to medicine in that they were essentially observers and experimenters. Many of the concepts that had been held for many years on the basis of speculation, or, at most, of simple observation, had at that stage of medical history become the subjects of planned experiment. This was a most significant development in the period we have been discussing.

Andral prided himself on being an 'eclectic'. That is, he tied himself to no particular dogma or 'system' but was content to collect facts and draw conservative conclusions from them without trying to fit them into any preconceived theory. In all his works he tried to maintain a balance between the dogmas of the various schools. Thus, he and his co-author in the work under discussion tried to maintain a balance between humorism and solidism in an age that had been so preoccupied with the outstanding discoveries that had just been made in morbid anatomy that studies of the body fluids had been relatively neglected. Although Andral was himself an eminent morbid anatomist, mere structural change was not his chief interest. What interested him most were the mechanisms that brought about physiological and pathological changes. In the article we have been discussing we have an excellent example of this interest.

\section{$A P P E \mathcal{N D} I X$}

\section{ANDRAL AND FORGET'S REFERENGES TO EARLIER WORK}

Les auteurs anciens ont servilement reproduit les théories humorales imaginées par Hippocrate et surtout Galien, jusqu'au temps où l'iatrochimie vint substituer de nouvelles hypothèses à celles de l'antiquité. Ce n'est, à vrai dire, que depuis Morgagni que les altérations du sang ont été matériellement démontrées et rationnellement expliquées. Nous nous bornerons à signaler les documens principaux.

MORGAGNI, J. B. De sedibus et causis morborum, epist. I et $5,176 \mathrm{r}$.

HUNTER, J. A treatise on the blood, inflammation and gun-shot wounds. London, 1795, in-4. New edition, 1828 , in-8.

Legallors, C. Le sang est-il identique dans tous les vaisseaux qu'il parcourt, Paris, an XI. Ce mémoire contient le germe des idées modernes sur l'absorption. Frappé de ce que certaines substances ingérées communiquent de l'odeur aux urines, Legallois se servit de ces faits sans prouver que certaines matières peuvent échapper à l'action d'assimilation et passer dans le sang.

DeYeuX, N. Considérations chimiques et médicales sur le sang des ictériques (1804). Ce travail a servi de point de départ à ceux de MM. Orfila, Clarion, Chevreul, Lassaigne, Braconnot, Lecanu, etc., sur le même sujet.

Ribes, F. 'Exposé sommaire de quelques recherches anatomiques, physiologiques et pathologiques.' Mémoires de la société médicale d'émulation, viI, 604, Paris, 1817.

Magendie et Delille. 'Expériences sur l'upas tieuté.' Journal de physiologie, 1821.

Gaspard. 'Expériences sur l'injection des matières putrides dans les veines' (Fournal de physiologie, 1822). Ce sont les deux mémoires précédens qui ont, pour ainsi dire,' donné l'éveil à l'humorisme moderne.

TIEDEMANN, F. et Gmélin. Recherches sur la route que prennent diverses substances pour passer de l'estomac et du canal intestinal dans le sang. Paris, 1821, in-8. Recherches experimentales, physiologiques et chimiques sur la digestion. Paris, 1827, 2 vol. in-8. 


\section{Some Notes on a Contemporary Review of Early French Haematology}

Fodera, M. Recherches expérimentales sur l'absorption et l'exhalation. Paris, 1823, in-8., fig.

Velpeau, A. A. Thèse, 1823. 'Divers mémoires sur les altérations du sang.' Revue médicale, 1826, II, II et IV, et 1829 .

Blandin, Ph. Thèse, 1824. 'Mémoire sur quelques accidens très communs à la suite des amputations des membres.' Fournal hebdomadaire de médecine, II, 1829 .

Rосна ux. 'De l'altération des humeurs dans les maladies.' Nouvelle Bibliothéque médicale, 1823. 'Maladies avec ou par altération du sang.' Archives générales, xII. 'Des systèmes en médecine, et principalement de l'humorisme, considérés dans leurs rapports avec la nosologie.' Journal hebdomadaire, $\mathrm{n}, 1829$.

LEURET, F. et LASSAIGNe. Recherches physiologiques et chimiques pour servir d l'histoire de la digestion. Paris, 1825 , in-8.

Dutroghet, H. De l'agent immédiat du mouvement vital. Paris, 1826, in-8.

TROUsse A U and DuPUY. 'Expériences et observations sur les altérations du sang, considérées comme causes ou comme complications des maladies locales.' Archives géntrales, II.

Trousseau et Rigot. 'Mémoire sur les colorations cadavériques des artères et des veines.' Archives géntrales, xrv.

Bouil Laud, J. Traité clinque et expérimental des fièvres dites essentielles. Paris, 1826 , in-8.

KALTENBRUUNER, G. Experimenta circa statum sanguinis et vasorum inflammatione. Stuttgard, 1826 , in-4, fig.

LEURET, F. Essai sur l'alteration du sang. Thèse, 1826 .

LEURET, F. et HAMONT. 'Expériences sur le traitement des affections produites par l'injection de matières putrides dans les veines.' Nonvelle Bibliotheqque médicale, 1827.

Marechal. These, 1828 .

Dance. 'De la phlébite utérine et de la phlébite en général.' Archives générales de médecine, Xvim et xxx.

Rose. 'Observ. on deposit. of pus.' Transact. med. chir., 1829.

ARNOTT. 'On the secondary effects of the infl. of veins.' Transact. med. chir., 1829.

Andral, G. Précis d'anatomie pathologique. Paris, 1829, 3 vol. in-8. Clinique médicale, $3^{\bullet}$ édition. Paris, 1835,5 vol. in -8 .

Lobste in, F. Traite d'anatomie pathologique. Paris, 1829-33, 2 vol. in-8.

Gruveil hie R, J. Anatomie pathologique du corps humain. Paris, 1834, in-fol., fig. coloriées, $\mathrm{r}^{\text {"r, }}$ art. 'Phlébite', livraisons rv', xi', xm', xvi'.

Lecanu. 'Mémoire sur l'analyse du sang, 1830. Nouvelles recherches sur le sang.' Annales de chimie et de physique, XIVIr, 308. 'Lettre sur l'état du sang dans le choléramorbus.' Transactions médicales, $\mathbf{x x}$.

STEVens, W. Observations on the healthy and diseased properties on the blood. London, 1832, in-8. Denis, S. Recherches experimentales sur le sang humain, consideré d l'etat sain. Paris, 1831, in-8.

Prorry. 'Recherches sur le sérum du sang.' Collection de mémoires, 1831 .

Mulle R. 'Observations sur la coagulation du sang.' Annales des sc. nat., 1832.

SABAtir R. 'Y a-t-il des métastases purulentes.' These du concours pour l'agrégation. Paris, 1832. WAGNER, R. Zur vergleichendon physiologie des blutes. Leipsig, 1833, in-8.

Rосне, L. Gн. 'Considérations sur les altérations du sang dans les maladies.' Fournal universal hebdomadaire, 1833. Nouveaux elémens de pathologie médico-chirurgicale, $3^{*}$ édition, Paris 1833 , $\mathrm{v}, 645$.

Everts, B. H. Dissertatio physiologico-medica de haemetosi, Lugduni Batavorum. 1834, in-8.

Forgrt, C. 'De l'humorisme rationnel.' Journal hebdomadaire, 1834-5.

Hermann. 'Recherches sur le sang des cholériques.' Archives de la medecine homoepathique. 1835, $\mathrm{n}$, in $-8^{\circ}, 355$.

Voyez les travaux de M. Magendie sur la gravelle (art. 'Gravelle', $\mathrm{xx}$ de ce dictionnaire); de Prévost et Dumas sur la présence de l'urée dans le sang (Annales de chimie et de physique, XXIII); de Chevreul sur la matière colorante de la bile trouvée dans le sang (Dictionnaire des sciences naturelles, XLVII), de F. Boudet, 'Nouvelles recherches sur la composition du serum du sang humain' (Annales de chimie et de physique, LII, 337); et Raspail, Nouveau systéme de chimie organique, Paris, 1829 , in-8, fig. 


\section{L. Verso}

\section{REFERENCES}

Dreyfus, C. (1957) Some Milestones in the History of Hematology, Grune and Stratton, New York and London.

Duguid, J. B. (1946) 'Thrombosis as a factor in the pathogenesis of coronary atherosclerosis.' 7. Path. Bact., LVII, 207.

Rokitansky, G. A Manual of Pathological Anatomy, translated by George E. Day, London, I852, IV, 272. 